\title{
PENINGKATAN SUMBER DAYA MANUSIA \\ (Perspektif Pendidikan Islam)
}

\author{
Oleh: Mastang Ambo Baba ${ }^{1}$
}

\begin{abstract}
Abstrak
Setiap kali bangsa dilanda krisis, pendidikan segera menjadi obyek sorotan. Mengapa bangsa menjadi begini dan begitu? Apa yang telah dilaksanakan oleh pendidikan untuk bangsa ini? konsekwensi tersebut wajar dan harus diterima oleh pendidikan karena memang permasalahan ini sangat erat kaitannya dengan peranan pendidikan sebagai agen perubahan dan pembentukan masa depan bangsa. Pendidikan Islam memiliki karakteristik yang koheren pada berbagai komponennya, baik menyangkut filsafat, materi, maupun prosesnya. Sehingga, pendidikan Islam akan memberi solusi bagi pemecahan krisis yang dihadapi oleh bangsa dan umat, suatu kemampuan yang akan mempertegas fungsi reformatifnya dan perannya sebagai pembentuk masa depan
\end{abstract}

Kata Kunci: Pendidikan Islam, Sumber Daya Manusia, berkualitas

\section{Pendahuluan}

Di dunia ini, setiap orang memiliki hak yang sama untuk mendapatkan pendidikan. Permasalahan pendidikan yang selalu menjadi pertanyaan adalah, bagaimana meningkatkan kualitas kehidupan manusia.

Untuk menjadikan manusia yang berkualitas, maka dibutuhkan pendidikan yang berkualitas pula. Pendidikan yang berkualitas diharapkan sebaiknya lebih fleksibel, terbuka, beragam, dan dapat diikuti oleh siapa saja yang membutuhkan tanpa memperhitungkan usia, jenis kelamin, pengalaman pendidikan sebelumnya, dan sebagainya.

Moderninisasi telah melahirkan era baru sejarah peradaban manusia melalui suatu proses sekularisasi dan inovasi, untuk melawan tradisi dan masa lalu yang bersifat statis. Pada satu sisi, modernitas telah melahirkan kemajuan sains, teknologi, industri, sehingga menghantarkan umat manusia ke puncak peradabannya.

\footnotetext{
${ }^{1}$ Penulis adalah dosen tetap pada Jurusan Tarbiyah STAIN Manado.
} 
Kecanggihan sains dan teknologi modern telah memungkinkan manusia untuk membangun sebuah peradaban yang canggih, penuh warna dan dinamika serta membuat tradisi kehidupan manusia dalam berbagai bidang menjadi sangat efektif dan efisien. ${ }^{2}$

Pada sisi lain, keyakinan dan ketergantungan berlebihan pada kemampuan sains dan teknologi telah melahirkan dehumanisasi, destruksi lingkungan, dan politik totaliter. Akibatnya, sebagian manusia modern terjauh dari nilai-nilai kemanusiaan, mengalami proses dehumanisasi dan krisis nilai-nilai spiritualitas.

Interaksi dan benturan semangat inovasi dengan sains dan teknologi yang tidak terkontrol serta tanpa kompromi dengan nilai-nilai kemanusiaan dan spiritualitas, menurut hasil penelitian dari UNESCO telah mengalami berbagai bentuk ketegangan dilematik dalam kehidupan manusia modern. Ketegangan tersebut meliputi 7 (tujuh) aspek, ${ }^{3}$ yakni :

1. Ketegangan antara global dan lokal

2. ketegangan antara universal dan individual

3. ketegangan antara tradisi dan modernitas

4. ketegangan antara jangka panjang dan jangka pendek

5. ketegangan antara kebutuhan bersaing dan pemerataan

6. ketegangan antara kebutuhan akan perluasan ilmu pengetahuan dan teknologi yang canggih dan kemampuan daya serap sumber daya manusia untuk secara cepat mencernanya, dan

7. ketegangan antara kebutuhan spiritual dan material.

${ }^{2}$ Douglas Kellner, Critical Theory, Marxism and Modernity (Baltimore : The Johns Hopkins University Press, 1989), h. 3.

${ }^{3}$ Mastuhu, Mencari Paradigma Baru Pendidikan yang Lebih Baik, Ta'dib, No. 04 Tahun 2001, h. 2-3. 
Berbagai dimensi ketegangan tersebut seringkali menimbulkan ketidakpastian, ketidakberdayaan, dan kesulitan dalam kehidupan manusia. Di negara-negara yang berkembang, termasuk Indonesia situasi kehidupan menjadi lebih buruk karena rendahnya kualitas dan kuantitas sumber daya manusia. ${ }^{4}$ Rendahnya kualitas sumber daya manusia membuat ilmu pengetahuan dan teknologi di berbagai negara gagal memberikan kesejahteraan bagi masyarakat. Sebaliknya, justru menimbulkan berbagai ekses negatif yang dapat merugikan masyarakat.

Manusia adalah agen perubahan dan pendidikan merupakan alat perubahan. Maka untuk menciptakan masyarakat yang islami serta berkualitas, pendidikan Islam harus dijadikan alat perubahannya. Pendidikan adalah proses pengubahan tingkahlaku manusia menuju tujuan yang dikehendaki.

Selama 13 tahun di Mekkah Rasulullah saw. Telah mendidik sahabatsahabatnya dengan aqidah dan akhlak Islam, sehingga tabah dalam memikul beban dakwah Islam dan tugas membentuk masyarakat Islam. Hasil pendidikan tersebut tampak pada masyarakat Madinah ketika Islam menjadi Negara dan masyarakat Islam di bawah naungan Negara Islam. Pendidikan Islam di masyarakat Madinah telah berhasil membentuk manusia yang beriman kepada Allah RasulNya.

Di masa sekarang, tanggung jawab pendidikan Islam berada di pundak para Pendidik Muslim. Mereka bertugas mendidik generasi muda dengan aqidah dan akhlak Islam agar menjadi manusia yang shaleh serta berkualitas.

Berdasarkan pemikiran tersebut di atas, maka dalam tulisan ini yang menjadi permasalahan utama adalah: "Bagaimana Peranan Pendidikan Islam dalam Membentuk sumber daya manusia yang berkualitas? Dengan pembahasan ini diharapkan dapat memberikan masukan dan sumbangan yang berguna bagi pihak-

${ }^{4}$ Ibid., 4-5. 
pihak yang terkait, seperti para Pendidik, Tokoh Masyarakat serta stakeholders dalam rangka menciptakan peserta didik yang berkualitas.

\section{Pendidikan Islam dan Tantangan Masa Kini}

Pendidikan Islam dewasa ini menghadapi banyak tantangan yang berusaha mengancam keberadaannya. Tantangan tersebut merupakan bagian dari sekian banyak tantangan global yang memerangi kebudayaan Islam dan kadang-kadang tampak dalam kedok politik, pendudukan militer, dan perang kebudayaan. Semuanya seperti terjalin dalam satu kekuatan yang berupaya memperdaya Islam dan pemeluknya. ${ }^{5}$

Tantangan pertama, ialah kebudayaan Islam berhadapan kebudayaan Barat Abad ke-20.Tantangan ini apabila tidak direspon oleh para pemikir muslim yang ikhlas dapat meningkat menjadi ancaman bagi kebudayaan Islam, mengingat kebudayaan Barat didukung oleh buku-buku, radio, bioskop, televisi, dan surat kabar yang tersebar ke berbagai negeri muslim. Sehingga, generasi muda muslim mesti dilindungi dengan usaha terpadu para pembela kebudayaan Islam dengan berbagai spesialisasinya.

Tantangan yang dihadapi kebudayaan Islam sekarang meliputi berbagai sektor : politik, militer, kebudayaan, dan sosial. Tantangan tersebut semakin menukik kepada penghancuran syiar Islam di dalam masyarakat muslim. Pendidikan Islam mempunyai tugas untuk mengungkap rahasia semua tantangan itu dalam upaya melindungi generasi muda, agar tidak diracuni kesalahpahaman yang disebarkan orang-orang yang tidak bertanggung jawab. Tugas tersebut hendaknya mampu membuat mereka

${ }^{5}$ Lihat Q.S. al-Shaff (61): 8 :"Mereka ingin hendak memadamkan cahaya (agama) Allah dengan mulut (ucapan-ucapan) mereka, dan Allah tetap menyempurnakan cahaya-Nya meskipun orang-orang kafir benci”. 
bersikap positif dalam upaya menggali karakteristik asli agama dan warisan umat sejalan dengan nafas kemajuan sambil tetap berpegang pada dasar-dasar yang kokoh. ${ }^{6}$

Tantangan kedua, bersifat intern tampak pada kejumudan produktifitas pemikiran keislaman dan upaya menghalangi produktifitas tersebut. Tantangan ini telah membuat generasi muda muslim terpenjara dalam kebudayaan materialistikpenyerang dengan berbagai media massa dan teknologinya yang canggih. Para pemikir dan ulama muslim tidak diberi kesempatan untuk memproduksi buku-buku atau menyampaikan ceramah-ceramah yang dapat menghalau tipu daya"para penyerang" yang membuat generasi muda muslim seperti kehilangan akal sehatnya, sehingga memungut "sisa-sisa hidangan" pikiran orang.

Setiap intelektual muslim perlu memikirkan upaya memproduksi segala sesuatu yang berguna bagi perpustakaan Islam dalam rangka menghadapi berbagai tantangan dan menolak kesalahapahaman tentang Islam, di samping memberi bekal islami kepada generasi muda untuk memainkan peranannya dalam membangun masa depat umat.

Tantangan ketiga, kebudayaan yang dimiliki oleh sebagian generasi muslim yang sedang belajar di negeri asing hanya kebudayaan asing. Apabila kembali ke negeri asal, mereka bias meniru kebudayaan asing secara buta dan membawa filsafat Barat yang tidak sesuai dengan realitas dan warisan kebudayaan mereka.

Penekanan di atas bukan provokasi untuk mengisolir diri dari global dan universal. Ini lebih merupakan imbauan agar para pemuda muslim yang belum matang dasar-dasar Islamnya tidak diutus untuk belajar ke negeri-negeri nonmuslim. ${ }^{7}$

${ }^{6}$ Q.S. al-Anbiya (21) : 107 : "Dan tiadalah Kami mengutusmu melainkan agar kamu menjadi rahmat bagi alam semesta". 
Tantangan keempat, system kebudayaan Islam di sebagian Negara Muslim masih terpaku pada metode tradisional dan kurang merespon perkembangan zaman secara memadai agar generasi muda tidak berpaling kepada kemewahan kehidupan modern dan kebudayaan Barat. Kebudayaan Islam di Negara-negara tersebut belum membekali mereka dengan konsep Islam yang komprehensif tentang kehidupan Islami yang didasarkan atas ilmu dan amal serta aqidah dan jihad. Konsep yang dimaksud ialah bahwa Islam merupakan system kehidupan yang mampu menyelesaikan berbagai persoalan, seperti persoalan ekonomi, sosial, budaya, dan lain-lain dengan metode orisional-elastis yang di satu sisi memelihara dasar-dasar Islam dan di sisi lain memenuhi tuntutan zaman.

Tantangan kelima, kurikulum Universitas di sebagian dunia Islam masih mengabaikan kebudayaan Islam. Alasannya, Universitas hanya bertugas menghasilkan tenaga-tenaga terampil bagi masyarakat, sedangkan pembekalan keagamaan menjadi tugas fakultas-Fakultas keagamaan. Sehingga, ada dikotomi antara ilmu umum dengan ilmu agama seperti halnya yang dilakukan oleh ahli pendidikan Inggris di Mesir dimulai sejak masa Dunlop, yang menciptakan 2 (dua) kelompok intelektual yakni intelektual keagamaan (ulama) dan intelektuan modern, sehingga terjadi konflik antara keduanya.

Realitas di atas hendaknya dipahami sebagai persoalan umat, kurikulum di sekolah dan Universitas pertama-tama hendaknya berisi kebudayaan Islam. Setelah itu, dilakukan pengkajian terhadap kemungkinan mengintegrasikan kebudayaan tersebut dalam pembahasan kurikulum-kurikulum lain. Dengan kurikulum seperti ini akan menghasilkan/melahirkan Intektual Muslim yang akan menyiarkan risalah Islam dan merealisasikan tujuan dakwah sesuai dengan spesialisasi dan metode masing-

${ }^{7}$ Disampaikan oleh Prof. Dr. Nasir A. Baki,M. A dalam Kuliah Tamu Jurusan Tarbiyah Sekolah Tinggi Agama Islam Negeri (STAIN) Manado pada Tanggal 28 Juli 2008 di Aula STAIN Manado. 
masing yang saling melengkapi. Tanpa kordinasi semacam ini, maka konflik alam pikiran akan tetap menggrogoti generasi intelektual Muslim.

Tantangan-tantangan tersebut di atas menambah tugas dan kewajiban Pendidikan Islam dan para Pendidik Muslim. Oleh sebab itu, diperlukan ekstra kesadaran akan ancaman bahaya serta perencanaan yang baik untuk memperluas disiplin keislaman ke berbagai bidang dan mengembangkan metode Pendidikan Islam agar mampu menghadapi berbagai tantangan zaman modern.

Melihat realitas sekarang ini tentang rendahnya kualitas dan kuantitas sumber daya manusia. Rendahnya kualitas sumber daya manusia membuat ilmu pengetahuan dan teknologi di berbagai negara dianggap telah gagal memberikan kesejahteraan bagi masyarakat, sebaliknya justru menimbulkan berbagai ekses negatif yang dapat merugikan masyarakat.

Berbagai ekses negatif ilmu pengetahuan dan teknologi tentu dapat dihindari apabila kita benar-benar “menguasai”nya, bukan “dikuasai”nya. Menguasai ilmu pengetahuan dan teknologi tidak hanya mengadopsi, mentransfer, dan menerapkan ilmu Pengetahuan dan Teknologi, tetapi juga melakukan adaptasi, yakni membingkai Ilmu Pengetahuan dan Teknologi dengan nilai-nilai sosial,budaya, dan agama serta menyesuaikannya dengan situasi,potensi dan kebutuhan riil. Sebagaimana yang dikutip dalam Mastuhu yang menyatakan bahwa : "Dengan menempatkan Ilmu Pengetahuan dan Teknologi sebagai bagian esensial dari ajaran agama (Islam), maka kita dapat menghindari terjadi proses dehumanisasi dan despritualisasi. ${ }^{8}$

Dalam ajaran Islam, aktifitas penguasaan Ilmu Pengetahuan dan Teknologi adalah perintah agama dan penguasaan terhadap ilmu pengetahuan dan teknologi adalah karunia Allah. Hubungan antara Islam dan ilmu pengetahuan dan teknologi

${ }^{8}$ Mastuhu, op. cit., h. 7. 
sangat dekat, sehingga semua kegiatan ilmu pengetahuan dan teknologi apapun jenisnya sepanjang untuk kemanfaatan manusia dan untuk mencegah kemudlaratan adalah perintah Islam.

\section{Pendidikan Islam Dalam Dinamika Masyarakat}

Membahas pendidikan dalam konteks dinamika sosial kultural masyarakat merupakan bidang kajian yang sangat luas, sehingga memerlukan berbagai kerangka analisis dari disiplin keilmuan lainnya. Di sini pendidikan diletakkan dalam konteks yang bersifat makro, yaitu pendidikan sebagai proses kebudayaan. Sebagai proses kebudayaan, maka yang perlu disadari bahwa pendidikan tidak mungkin mengisolasi dirinya dari perkembangan dan transformasi, baik secara kultural, sosial, maupun struktural.

Dalam kajian teoritik seringkali diperdebatkan, apakah perubahan atau dinamika dalam masyarakat merupakan perubahan budaya (cultural change), perubahan yang berhubungan dengan ide-ide dan nilai-nilai yang dianut oleh kelompok masyarakat, atau perubahan sosial (social change), yakni perubahan di bidang pola hubungan dalam masyarakat dan perkembangan kelembagaannya. Kedua perubahan itu mempunyai hubungan timbal-balik. ${ }^{9}$

Definisi yang dibuat oleh Selo Sumarjan dalam bukunya Soejono Soekanto yang berjudul Sosiologi Suatu Pengantar membuat definisi untuk perubahan sosial yang diartikan sebagai perubahan-perubahan pada lembaga-lembaga kemasyarakatan di dalam suatu masyarakat yang mempengaruhi sistem sosialnya, termasuk di

\footnotetext{
${ }^{9}$ Sudharto, Penelaahan Teori tentang Perubahan Sosial, dalam M. Rusli Karim, Seluk-Beluk Perubahan Sosial (Surabaya : Usaha Nasional, tt), h. 35.
} 
dalamnya nilai-nilai, sikap-sikap, dan pola-pola perilaku di antara kelompokkelompok dalam masyarakat. ${ }^{10}$

Persoalan penting yang terkait dengan poin pertama adalah bagaimana memetakan perubahan yang bakal terjadi di masa depan dan inplikasinya bagi pendidikan Islam ? Atau dalam bahasa yang lain, bagaimana seharusnya pendidikan Islam memposisikan dan memerankan dirinya dalam setiap perubahan yang sedang dan akan terjadi ?

Gambaran dari realitas dalam masyarakat akhir-akhir ini adalah adanya pergeseran pandangan terhadap pendidikan seiring dengan tuntutan masyarakat yang berkembang. Kini masyarakat melihat pendidikan tidak lagi dipandang hanya sebagai bentuk pemenuhan kebutuhan terhadap perolehan pengetahuan dan keterampilan dalam konteks waktu sekarang. Di sisi lain, pendidikan dipandang sebagai bentuk investasi, baik modal maupun manusia (human and capital investmen) untuk membantu meningkatkan keterampilan dan pengetahuan sekaligus mempunyai kemampuan produktif di masa depan yang diukur dari tingkat penghasilan yang diperolehnya. ${ }^{11}$

Saat ini, masyarakat sudah mulai selektif dalam memilih lembaga pendidikan dari tingkat Taman Kanak-Kanak sampai Perguruan Tinggi. Perubahan demikian merupakan akibat dari rangkaian perubahan yang terjadi. Artinya, perubahan yang terjadi di dalam masyarakat dalam bidang yang lain mempengaruhi pula pandangan dan pilihan masyarakat terhadap pendidikan. Pendidikan yang akan dipilihnya sudah barang tentu yang dapat mengembangkan kualitas dirinya sesuai dengan perkembangan masyarakat.

\footnotetext{
${ }^{10}$ Soejono Soekanto, Sosiologi Suatu Pengantar (Jakarta : PT. Rajawali, 1986), 43.

${ }^{11}$ Ace Suryadi dan HAR Tilaar,Analisis Kebijakan Pendidikan Suatu Pengantar (Bandung : : Rosdakarya, 1993), h. 86.
} 
Sesuai dengan ciri masyarakat tersebut, maka pendidikan yang akan dipilihnya adalah pendidikan yang dapat memberikan kemampuan secara teknologis, fungsional,individual, informatif, dan terbuka. Dan yang lebih penting lagi, kemampuan secara etik dan moral yang dapat dikembangkan melalui agama.

Dari semua rangkaian pembaruan di atas, pada akhirnya kita mempertanyakan posisi dan peran pendidikan Islam di Indonesia. Dalam konteks inilah akan dijumpai,betapa pendidikan Islam - yang dari segi kuantitas menunjukkan perkembangan yang dinamis mulai dari Taman Kanak-Kanak sampai Perguruan Tinggi - menghadapi berbagai persoalan. Tidak saja pada persoalan tataran normatiffilosofis, akan tetapi juga menyangkut orientasi kultural di masa depan.

Dalam tataran normatif-filosofis, hingga kini selalu berkutat perdebatan semantik, apakah pendidikan Islam secara peristilahan menggunakan istilah tarbiyah, ta'lim, atau ta'dib. Dari segi konten, pendidikan Islam masih dihadapkan pada persoalan dualisme-dikotomi antara ilmu-ilmu agama dan ilmu-ilmu umum.

Selain itu, pendidikan Islam masih belum menuntaskan konsep-konsep normatif yang berhubungan dengan cita ideal manusia yang ingin dihasilkan. Jika pendidikan Islam bertujuan mencetak manusia yang baik (menurut Muhammad Naquib al-Attas), maka pertanyaannya, manusia yang bagaimanakah yang baik itu ? masalah inilah yang masih mengundang perdebatan pada persoalan normatif filosofis.

Misalnya,konsep sholeh, taqwa, dan insan kamil sebagai parameter dari manusia yang baik. Pemaknaan terhadap konsep ini terkesan masih jauh dari gambaran cita ideal manusia yang diharapkan. Ironisnya, masih saja dijumpai pandangan bahwa yang disebut dengan kesholehan dan ketaqwaan adalah jika 
intensitas ritual seseorang tinggi. Karena persoalan yang paling mendasar belum diselesaikan secara tuntas.

Oleh karena itu, pendidikan Islam diperhadapkan pada persoalan ketidakjelasan orientasi kultural. Bukti dari adanya persoalan ini tampak pada belum diselesaikannya hubungan Islam dengan modernitas. Apakah pendidikan Islam ingin lebih menampilkan watak tradisionalnya dengan mengidealisasikan masa lalu,seraya mengkritik pendidikan modern karena dianggap berbau sekuler ? atau ingin lebih menampilkan watak yang lebih fragmatis dan progresif, seraya mengecam orientasi pendidikan yang cenderung tradisionalistik dengan memuja pendidikan modern ? dengan hanya menyebut dua bidang persoalan fundamental tersebut, sudah bisa dijadikan kerangka hipotesis dalam menilai kemampuan pendidikan Islam dalam memposisikan dan memerankan dirinya di masa depan.

Pendidikan Islam dituntut melakukan fungsi yang bersifat reflektif dan progresif. Artinya, pendidikan Islam harus mampu menggambarkan corak dan arus kebudayaan yang sedang berlangsung, juga dituntut mampu memperbarui dan mengembangkan kebudayaan agar dicapai kemajuan sehingga pendidikan Islam menjalankan kegiatan transformasi.

\section{Profil Sumber Daya Manusia Yang Berkualitas}

Menurut Abraham Maslow ${ }^{12}$, sumber daya manusia berkualitas adalah sumber daya manusia yang mampu mengaktualisasikan diri, yaitu memiliki karakteristik, antara lain (1). Dapat menerima dirinya, orang lain, dan lingkungan sekitar, (2) Berpandangan realistik, (3) Tidak bersikap pasrah, (4) Berorientasi pada problemproblem eksternal, bukan pada dirinya, (5) Mengapresiasi kebebasan dan kebutuhan

\footnotetext{
${ }^{12}$ Abraham Maslow, Motivation and Personality (New York, Harper, 1954), h.
} 
akan spesialisasi, (6) berkepribadian independen dan bebas dari pengaruh orang lain, (7) hubungan dengan orang lain sangat kuat dan mendalam, bukan sekedar formalitas, (8) Arah dan norma demokratisnya diliputi oleh sikap toleran dan sensitifitasnya, (9) Menentang ketaatan dan kepatuhan buta terhadap budaya, berjiwa riang secara filosofis, tidak bermusuhan, (10) Dan lain-lain.

Selanjutnya, menurut Erich Fromm dalam Mursi,mengidentifikasikan kualitas sumber daya manusia melalui 5 (lima) jenis kepribadian : Pertama, kepribadian pasrah dan pasif. Pemilik kepribadian ini yakin bahwa apapun yang diinginkannya harus tercapai tanpa usaha atau kegiatan untuk memperolehnya dan harus diperolehnya secara pasif dan pasrah.Kedua, kepribadian vested interest. Pemilik kepribadian ini berusaha memperoleh segala sesuatu dari orang lain,baik dengan cara tipuan maupun dengan kekerasan, dan menganggap semua orang sebagai sasaran baginya. Ketiga, kepribadian posesif. Pemilik kepribadian ini suka menyimpan segala sesuatu yang dia peroleh. Ketegangan batinnya dan ketentraman hatinya tergantung pada tabungan dan simpanannya. Dia senantiasa melestarikan miliknya dan merasa bahwa membelanjakan sesuatu akan mengancam hidupnya. Baginya, cinta adalah memiliki. Keempat, kepribadian berorientasi pasar, kepribadian ini menyerupai kepribadian penjual. Pemilik kepribadian ini merasa bahwa kepribadiannya dapat diperjualbelikan, dan terpengaruh oleh tuntutan eksternal yang berubah-ubah. Menurutnya, orang yang sukses adalah bernilai jual. Kelima, kepribadian produktif. Seseorang akan memiliki kepribadian produktif apabila dia mampu mengembangkan potensi., mampu berpikir bebas dan kritis. Dengan kata lain, orang yang berkepribadian produktif adalah orang yang mampu memantapkan dan 
mengaktualisasikan diri serta mengambil hal-hal positif dalam kehidupan. ${ }^{13}$ Keistimewaan dari kepribadian produktif dalam konteks pekerjaan, yaitu :

1. Dapat meningkatkan kuantitas dan kualitas produksi

2. Dapat menekan fenomena-fenomena negatif yang dapat menghambat produksi, seperti keterlambatan, inefisiensi pemakaian bahan baku, penyimpangan, sakit, dan konflik.

3. Jika mempimpin, membimbing, dan mengelola dapat melakukannya dengan baik dan bertanggung jawab. ${ }^{14}$

Beberapa pendapat tentang kualitas sumber daya manusia yang tersebut di atas sangat menekankan faktor biologis, sosial, dan kebudayaan dan cenderung mengabaikan faktor ruh atau batin yang merupakan unsur penting yang terdapat di dalam diri manusia yang berdampak terhadap kepribadian.

Padahal, kepribadian manusia hanya dapat dilihat dengan jelas dari seluruh faktor kepribadian, baik yang material maupun spiritualnya (unsur jasmani dan rohani). Jasmani mempresentasikan dimensi material sedangkan rohani mempresentasikan dimensi spiritual, masing-masing unsur tersebut memiliki kebutuhan dan fungsi yang berbeda-beda yang harus dipenuhi dan diperhatikan. Apabila keduanya tidak mendapat perhatian secara seimbang, maka akan terjadi konflik. $^{15}$

Situasi atau kualitas jiwa seseorang adalah inner drive yang menentukan apa yang dapat dia lakukan, mengapa dia melakukannya, dan bagaimana dia

\footnotetext{
${ }^{13}$ Abdul Hamid Mursi, Sumber Daya Manusia yang Produktif : Pendekatan al-Qur'an dan Sains (Jakarta :Gema Insani Press, 1997), h. 47-49.

${ }^{14}$ Ibid., h. 28-30.

${ }^{15}$ Muhammad Utsman Najati, al-Qur'an wa "Ilmal-Nafs (Kairo : Dar al-Syuruq, 1982), h. 200-201.
} 
melakukannya. Oleh karena itu, pembinaan sumber daya manusia dalam bidang apapun, termasuk dalam bidang ilmu pengetahuan dan teknologi perlu memberikan perhatian pada aspek pembinaan jiwa (tazkiyah al-Naf). Yang terpenting dari pembinaan jiwa manusia adalah keyakinan, menyakini adanya kebenaran dan rasa takut, cinta dan tunduk untuk mendekatkan diri kepada kekuatan yang paling sempurna, yakni Allah SWT.

Selanjutnya, Mursi ${ }^{16}$ membagi profil manusia ke dalam 3 (tiga) kelompok berdasarkan kualitas keyakinannya, yakni (1) al-Mukminun, (2) al-Kafirun, dan (3) al-Munafikun. Dari 3 (tiga) profil manusia tersebut menurut Mursi bahwa manusia yang berkemampuan atau memiliki inner qualities untuk meminimalisasi ekses negatif dari ilmu pengetahuan dan teknologi dan mengoptimalisasi dimensi positifnya hanyalah sumber daya manusia yang beriman (al-Mukminin). Dengan kata lain, sumber daya manusia yang beriman adalah sumber daya manusia yang memiliki keseimbangan antara kecerdasan intelektual (IQ), kecerdasan emosional (EQ), dan kecerdasan Spiritual (SQ).

Selain itu, menurut Ary Ginanjar "Manusia harus memiliki konsep duniawi atau kepekaan emosi dan intelingensia yang baik (EQ plus IQ) dan penting pula penguasaan ruhiyah vertikal atau Spriritual Quotien (SQ)". Kecerdesan emosi memiliki peran yang jauh lebih penting dibandingkan dengan kecerdasan intelektual (IQ). ${ }^{17}$

\footnotetext{
${ }^{16}$ Abdul Hamid Mursi, op.cit., h. 63.

${ }^{17}$ Ary Ginanjar Agustian, Rahasia Sukses Membangun Kecerdasan Emosi dan SpiritualESQ Emiotional Spritual Quotient Berdasarkan 6 Rukun Iman dan 5 Rukun Islam (Jakarta : Arga, 2001), h. xviii.
} 
Bahkan, para pakar Pendidikan sepakat bahwa EQ sangat penting dimiliki oleh siapapun, karena hanya sekitar $20 \%$ dari keberhasilan hidup yang ditentukan oleh IQ, sedangkan $80 \%$ sisanya ditentukan oleh faktor-faktor lain, di antaranya yang terpenting adalah EQ. ini dapat dimaklumi, karena hanya sumber daya manusia yang memiliki EQ yang memiliki self awareness (kesadaran diri), self regulation (pengaturan diri), motivation (motivasi), emphaty (empati), dan social skill (ketrampilan sosial). ${ }^{18}$

IQ dan EQ saja tidaklah cukup untuk membawa diri manusia dalam kebahagian dan kebenaran yang hakiki,masih ada nilai-nilai lain yang tidak biasa dipungkiri keberadaannya, yaitu kecerdasan spiritual (SQ). oleh karena itu, perlu mensinergikan potensi kecerdasan itu ke dalam satu formula yang dinamakan ESQ Model, yaitu formula yang menyatukan unsur IQ, EQ, dan SQ dalam satu kesatuan system yang terintegrasi. ${ }^{19}$

Dengan demikian, sumber daya manusia Imani harus menyadari bahwa ilmu pengetahuan dan teknologi yang dimiliki adalah amanah yang akan dipertanggungjawabkan di hadapan Allah SWT. Dapat dipahami pula bahwa tidak ada jarak antara iman dan ilmu, orang yang beriman akan terpacu untuk terus menuntut ilmu dan orang-orang yang berilmu akan semakin kuat imannya. Sehingga, tidak ada dikotomi antara "ilmu umum" dan "ilmu agama”. Ilmu pengetahuan dan teknologi akan lebih kokoh dan positif jika disinari oleh nilai-nilai agama dan nilai-

\footnotetext{
${ }^{18}$ Forum Kajian Budaya dan Agama (FKBA), Kecerdasan Emosi (Emotional Intelligence) \& Quantum Learning (Yogyakarta, 2000), h. 7.

${ }^{19}$ Lihat., Ary Ginanjar Agustian, Rahasia Sukses Membangkitkan ESQ Power: Sebuah Inner Journey Melalui al-Ihsan (Jakarta : Arga, 2003), h. 65.
} 
nilai agama akan lebih actual apabila didukung oleh sarana ilmu pengetahuan dan teknologi.

Oleh karena itu, sumber daya manusia perlu dididik agar tidak sekedar tahu tentang ilmu pengetahuan dan teknologi, tetapi harus juga dapat mengaplikasikannya bersama-sama dengan anggota masyarakat lainnya dan untuk kesejahteraan bersama. Kita harus menyadari bahwa ilmu pengetahuan dan teknologi bukanlah sekedar symbol kemajuan dan kemewahan, tetapi merupakan sarana untuk meningkatkan kesejahteraan bersama. Diharapkan kita tidak hanya fit secara fisik, tetapi juga harus fit secara batiniyah, yakni memiliki kemampuan dan pola pikir yang baik, mampu mengendalikan nafsu, dan memiliki jiwa yang sehat. Artinya, perlu memberikan forsi yang seimbang antara pembinaan jiwa, fisik, dan nalar.

\section{Kesimpulan}

Globalisasi telah membawa perubahan pada hampir semua aspek kehidupan manusia, di mana di berbagai permasalahan hanya dapat dipecahkan kecuali dengan upaya penguasaan dan peningkatan ilmu pengetahuan dan teknologi. Selain manfaat bagi kehidupan di satu sisi, perubahan tersebut juga telah membawa manusia ke dalam era persaingan global yang semakin ketat. Agar mampu berperan dalam persaingan global, maka perlu terus mengembangkan dan meningkatkan kualitas sumber daya manusianya. Pendidikan memegang peranan yang sangat penting dalam proses peningkatan kualitas sumber daya manusia. Peningkatan kualitas pendidikan merupakan suatu proses yang terintegrasi dengan proses peningkatan kualitas sumber daya manusia.

Sebagai pendidik dan peserta didik harus menyadari bahwa tujuan pendidikan yang ideal adalah membentuk manusia Indonesia seutuhnya, yaitu manusia yang 
mampu memadukan antara iman,ilmu, dan amal sehingga tercipta sumber daya manusia yang berkualitas.

Eksistensi pendidikan Islam dan peranannya dalam upaya menciptakan sumber daya manusia yang berkualitas tidak dapat diragukan lagi oleh siapapun juga. Oleh karena itu, pendidikan Islam adalah pendidikan untuk pertumbuhan total seorang manusia. Adalah kewajiban bagi kita semua untuk meneruskan eksistensi Pendidikan Bangsa dan Negara kita. 


\section{Daftar Pustaka}

\section{Al- Qur'an al-Kariim}

A. Baki, Nasir., dalam Kuliah Tamu Jurusan Tarbiyah Sekolah Tinggi Agama Islam Negeri (STAIN) Manado pada Tanggal 28 Juli 2008 di Aula STAIN Manado.

Agustian, Ary Ginanjar., Rahasia Sukses Membangun Kecerdasan Emosi dan Spiritual ESQ Emiotional Spritual Quotient Berdasarkan 6 Rukun Iman dan 5 Rukun Islam, Jakarta, Arga, 2001.

, Rahasia Sukses Membangkitkan ESQ Power: Sebuah Inner Journey Melalui al-Ihsan, Jakarta, Arga, 2003.

Forum Kajian Budaya dan Agama (FKBA), Kecerdasan Emosi (Emotional Intelligence) \& Quantum Learning, Yogyakarta, 2000.

Kellner, Douglas., Critical Theory, Marxism and Modernity, Baltimore, The Johns Hopkins University Press, 1989.

Mastuhu, Mencari Paradigma Baru Pendidikan yang Lebih Baik, Ta'dib, No. 04 Tahun 2001.

Maslow, Abraham., Motivation and Personality, New York, Harper, 1954.

Mursi, Abdul Hamid., Sumber Daya Manusia yang Produktif : Pendekatan al-Qur'an dan Sains, Jakarta, Gema Insani Press, 1997.

Najati, Muhammad Utsman., al-Qur’an wa “Ilm al-Nafs, Kairo, Dar al-Syuruq, 1982.

Sudharto, Penelaahan Teori tentang Perubahan Sosial, dalam M. Rusli Karim, SelukBeluk Perubahan Sosial, Surabaya, Usaha Nasional, tt.

Soekanto, Soejono., Sosiologi Suatu Pengantar, Jakarta, PT. Rajawali, 1986.

Suryadi, Ace dan HAR Tilaar., Analisis Kebijakan Pendidikan Suatu Pengantar, Bandung, Rosdakarya, 1993. 